\title{
IMPROVING STUDENTS' READING COMPREHENSION OF THE TWELFTH GRADE STUDENTS OF SMA NEGERI 1 BATANG KUIS THROUGH GROUP INVESTIGATION METHOD
}

\author{
Torang Maruli Sinurat, Anna Stasya Prima Sari, Novalina Sembiring
}

\begin{abstract}
Reading is not only about pronouncing written words correctly but also comprehending the text. It is not surprising that students have difficulties in reading comprehension. For example: Students cannot understand and share information of the text. Thus, there must be a method which can help them read effectively. Group Investigation method can help improve the students' reading comprehension and motivation to read. The objectives of this research are to find out that Group Investigation method improves students' reading comprehension and to describe the students' responses towards learning teaching process of reading comprehension through the application of Group Investigation method. This research is Classroom Action Research (CAR) which was conducted by applying Group Investigation method to the twelfth grade students of SMA Negeri 1 Batang Kuis. After six meetings, it could be seen that there is a significant improvement of the students' reading comprehension. The results of the tests showed that the students' mean score in the pretest is 60.25 with $15.62 \%$ of the students who got score $\geq 75$, the students' mean score in the formative test is 71.25 with $28.12 \%$ of the students who got score $\geq 75$, and the students' mean score in the posttest is 78.87 with $71.87 \%$ of the students who got score $\geq 75$. The quantitative data analysis showed that there is a significant mean score increase from pretest to posttest, namely about $56.25 \%$. The qualitative data analysis showed that the students' responses towards the application of Group Investigation method in the learning teaching processes of reading comprehension on narrative texts are very positive. They agree that the application of Group Investigation method could help them improve their reading comprehension. It is suggested that English teachers apply Group Investigation method as an alternative to improve their students' reading comprehension.
\end{abstract}

\section{Keywords: Reading Comprehension, Group Investigation Method, Classroom Action Research (CAR)}

\section{INTRODUCTION}

Reading is one of the most important skills that should be mastered by the students in learning English. Through reading, the students get much information, especially about the educational field. By reading do students not only get the information but also support another skill in English. Students must have good reading comprehension in order to get much information and knowledge.

According to Brassell and Rasinski (2008:15) reading refers to the ability to comprehend or make meaning from written texts. Furthermore, Klingner (2007:8) says, "Reading comprehension involves much more than readers' responses to text". Reading comprehension is a multi-component, highly complex process that involves many interactions between readers and writers. From the definition, the writer concludes that reading comprehension is a process to read a text in order to get information from the text. It means that when we read, we have to understand the information or issue written in the text.

There are some texts that the students learn in Senior High School. They are descriptive text, narrative text, procedure text, spoof text, discussion, explanation, report text, analytical exposition text, and hortatory exposition text. According the English syllabus of the twelfth grade of Senior High School in the first semester, students are expected to be able to 
comprehend report text, narrative text, discussion and explanation. Based on the first writer's interview with Mr. Anggiat, S.Pd, the teacher of English at SMA Negeri 1 Batang Kuis, most of the students could not understand the content of the text after they read it. As the result, they not only find difficulties to get the important information of the text but also answer the questions related to the text.

Based on the writer's observation toward the twelfth grade students of SMA Negeri 1 Batang

Kuis Class XII IPA in the Academic Year of 2016/2017 when they were learning narrative text, it was found out that they were unable to comprehend the narrative text well. They tended to focus on the words in the text rather than on the entire text. Therefore, they read slowly word by word and have unreasonable expectations about how much they should be able to comprehend. Besides, they lack of English vocabularies. It makes them rely on their dictionaries in order to find out the meanings of the difficult words. In addition, not all of the students took part actively in learning teaching process. There were many passive students in the class when the teacher was teaching.

The problems above should be solved immediately. Teachers have to consider a method that can help the students solve their problems in order to have good reading comprehension on narrative texts. Regarding the situation, the writer chose Group Investigation Method to solve the problems. Group Investigation is one of cooperative learning methods which is focused on student's participation and activity. Sharan and Sharan (1992-263) state that Group Investigation is a cooperative learning method to integrate interaction and communication in the classroom with the process of academic inquiry. Tan, et al. (2006:10) state, "Group Investigation method requires the students to form small interested groups, plan and implement their investigation, synthesize the group members' findings, and make a presentation to the entire class". Slavin $(2005: 218)$ states that in the Group Investigation method the students work through six stages: 1) Identifying the topic and organizing students into group, 2) Planning the learning task, 3) Carrying out the investigation, 4) Preparing a final report, 5) Presenting the final report, 6) Evaluation. Communication and cooperative interaction between the classmates will give the best result, because students have to work together.

The writers are interested in applying Group Investigation method in order to improve students' reading comprehension because some research findings have shown good results of teaching English reading comprehension through Group Investigation method. The first research was carried out by Sulistiono (2011) entitled "Improving Students' Reading Skill through Group Investigation Method at the Eleventh Grade of MA Arrisalah Ponorogo". She concluded that the use of Group Investigation method for teaching reading could make students feel interested and enthusiastic towards the English lesson, make students have solidarity and responsibility toward their friends and make the teaching and learning process conducive. It is stated that Group Investigation method can be used to increase students' reading comprehension. It statically had been proven by the increase of the students' mean score in posttest that is higher than the mean score in pretest. The mean score increased from 72.5 in pretest to 77.5 in posttest.

The second one was carried out by Rahmawati (2014) entitled "The Use of Group Investigation method to Improve Students' Reading Skill at the Tenth Grade of MAN Tengaran". She concluded that after using Group Investigation method the students' reading skill improves. It seems from the learning teaching, the students could think of the text, they become brave to give opinion, and they could read confidently. All of the students gave good responses to for the teacher when the learning teaching was taking place. It is stated that Group Investigation method can be used to increase students' reading comprehension. It statically had been proven by the increase of the students' mean score in posttest that is higher than the mean score in pretest. The mean score increased from 58.12 in pretest to 73.66 in posttest.

The third one was carried out by Febriyono (2015) entitled "The Use of Group Investigation Method to Improve Students' Reading Skill at the Tenth Grade Students of SMK Negeri Jumantono". He said by applying Group Investigation method, the students became more active in reading activities. They were also enthusiastic in learning reading skill and they were more confident in sharing their ideas to the whole class and gave more respect to others. The situation of teaching learning became cooperative. They worked in group to discuss the answers to the questions and shared the result of their discussion to the whole class. It is stated that Group Investigation method can be used to increase students' reading comprehension. It statically had been proven by the increase of the students' mean score in posttest that is higher than the mean score in pretest. The mean score increased from 64.27 in 
pretest to 80 in posttest. Thus Group Investigation method could improve the students' reading skill at SMK Negeri Jumantono.

This study is important to conduct because if it is not conducted, teachers will not be able to know students' problems in comprehending English texts and how to improve their reading comprehension. If language teachers do not know the students' problem in comprehending English texts, thus students will not get feedback from their teachers in order to be able to comprehend English texts. Meanwhile if this is conducted, it will give some positive impacts. This study will be so useful for language teachers that they will be able to know how far students have improvement in comprehending English texts. Based on the background of the study, the writers decided to conduct a research entitled Improving Students' Reading Comprehension of the Twelfth Grade Students of SMA Negeri 1 Batang Kuis through Group Investigation Method.

\section{REVIEW OF LITERATURE}

\subsection{Reading}

Reading is a way to draw information from the printed page and interpret the information appropriately. Cain (2010:2) states, "Reading is an important skill; it is much more than a single skill: it involves the coordination of a range of abilities, strategies and knowledge". The number and type of factors that are involved in reading, and the impact each has on the process, can be hard for skilled adult readers to appreciate, because reading is relatively effortless. Reading is an ability that we can quite easily take for granted.

Lucantoni (2005:29) says, "There must also be an interaction between the text and the receiver". Reading is a form of communication between the reader and the writer. In the reading process, a reader has to understand and catch the main idea of the text. At the same time, the writer tries to give understanding through the words. The readers have to understand each sentence what they are saying. Reading is related to the cognitive process. In this process, the readers must be active to use their mind to understand what they are reading. They also try to solve the problem by their intelligence. Besides, reading is an active skill. In the reading process, a reader must be able to guess, predict, check, and ask oneself some questions related to the text.

Woods (2005: 62) states that reading frequently seen as a passive skill, in that it is receptive skill rather than productive skill. Nevertheless, to have meaning for reading, readers need to be active in the learning process. They need to be able to relate to and to understand the text, and this is an interactive process, because reading needs an interactive process.

The reader and the writer are the subjects in the reading process. There is a connection between them. A writer tries to explain his/her idea and the reader tries to understand the text he/she reads. Many reading specialists define that the essence of reading is a transaction and communication between the words of the writer and the mind of the reader. From the fact above, the writer can conclude that reading is a mental process to read a text in order to get information from the text. It means that when we read, we have to understand the information or issue that is explained on the text.

\subsubsection{The Processes of Reading}

The process of reading refers to the process a person goes through to learn how to read. Nunan (2003:70) divides the models of reading processes into three categories: Bottom-up Models, Top-Down Models, and Interactive Models.

\section{Bottom-up Model}

The bottom up model typically consists of lower-level reading processes. Students start with the fundamental basics of letter and sound recognition, which in turn allows for morpheme recognition in what class followed by word recognition, building up to the identification of grammatical features, sentences, and longer texts. Letters, letter clusters, words, phrases, sentences, longer text, and finally meaning is the order in achieving comprehension.

\section{Top-Down Model}

The top down model, on the other hand, begins with the idea that comprehension resides in the reader. The reader uses background knowledge, makes prediction, and searches the text to confirm or reject the predictions that are made. A passage can thus be understood even if all of the individual words are not understood. Within a top-down approach to reading the teacher should focus on meaning generating activities rather than on mastery of word recognition. 


\section{Interactive Model}

This third type combines elements of both bottom-up and top-down models assuming that a pattern is synthesized based on information provided simultaneously from several knowledge sources. Nunan (2003:70) stresses, the best second language readers are those who can efficiently integrate both bottom-up and top-down processes.

\subsubsection{The Purposes of Reading}

Students must have a purpose when they are reading because students who are reading with a purpose cannot comprehend the text and know what they read better than those who have no purpose in reading. According to Grabe and Stoller (2002:13-15) the purposes of reading are classified into:

\section{Reading to Learn From Text}

Reading to learn typically occurs in academic and professional contexts in which a person needs to learn a considerable amount of information of a text. Reading to learn is usually carried out at a reading rate somewhat slower than general reading comprehension (primarily due to rereading and reflection) strategies to help remember information.

\section{Reading to Search for Simple Information and Reading to Skim}

Reading to search for simple information is a common reading ability though some researchers see it as a relatively independent cognitive process. It is used so often in reading task that it is probably best seen as a type of reading ability. Similarly, reading to skim to is a common part of many reading task and a useful skill in its own right. It involves, in essence a combination of strategies for guessing where important information might be in the text, and then using basic reading comprehension skills on those segments of the text until a general idea is formed.

\section{Reading for General Comprehension}

Reading for general comprehension is the most basic purpose for general. Underlying and supporting most other purposes for reading. General reading comprehension is actually more complex than commonly assumed. Reading for general information requires very rapid automatic processing of word, strong skills in forming a general meaning representation of main ideas and efficient coordination of many processes under very limited time constraints.

\section{Reading to Integrate Information, Write and Critique Text}

Reading to integrate information requires additional decisions about the relative importance of complementary, mutually supporting or conflicting information and the likely restructuring of a rhetorical frame to accommodate information from multiple sources. Both reading to write and reading to critique text require abilities to compose, select and critique information from a text.

\subsection{Reading Comprehension}

The main purpose of reading is comprehension. Reading comprehension is an attempt to understand, evaluate, and also recognize the author's ideas of reading text. A reader needs comprehension to catch the content of message or information from the text. Snow (2002:11) states, "Reading comprehension is defined as the process of simultaneously extracting and constructing meaning through interaction and involvement with written language". The process of constructing meaning is the process in which the reader combines their prior knowledge with the additional information from a text, draws the meaning of words, and connect it to reach the clear understanding of the written text.

Martin (1991:7) states, "Reading comprehension requires motivation, mental framework for holding ideas, concentration and good study technique". It means that in order to be successful in reading comprehension, the reader needs to motivate him/herself to concentrate on reading, try to form the mental frameworks for holding ideas, and the reader must have a good technique in reading. The process of comprehending involves decoding the writer's words and then using background knowledge to construct an approximate understanding of the writer's message.

Multiple choice questions, short answer questions, cloze test, and summarizing are examples of tasks used to assess comprehension. Language conveys meaning and allows the sharing of information, ideas, and perspectives. When written message are successfully understood, reading can be a wonderfully inspiring, enjoyable and transforming experience. The reader may comprehend a text when they can recognize the words and sentences of the text and know what the meaning is (obtain literal meaning), associate meaning both denotative and connotative from personal experiences and prior 
knowledge with the printed text, recognize how all these meanings and/or his perceptions of them fit together contextually, make value judgment about the reading experience. Reader has to find the idea that influence of the quality of their reading comprehension. From the explanation above, it is concluded that in reading comprehension, a reader must have available ability in the process of taking meaning from the text.

\subsubsection{Levels of Comprehension}

Burn, Roe \& Ross (1990:177) state that there are four levels of comprehension that must be achieved in reading comprehension. The four levels of reading comprehension are identified as follows: 1) Literal Comprehension

The basis of literal comprehension is recognizing main ideas, details, causes and effect, and sequences. It is important since it is as prerequisite for higher-level understanding. It means that the literal comprehension question test the readers' ability to think within the text and consider what has been literally and explicitly stated. There is no hidden meaning so the reader can take what is presented at face level.

\section{2) Interpretive Comprehension}

Interpretive comprehension consist of (1) inferring main ideas of passages in which the main ideas are not directly stated; (2) inferring cause-and-effect relationships when they are not directly stated; (3) inferring referents of pronouns; (4) inferring referents of adverbs; (5) inferring omitted words; and (6) drawing conclusion. It means that interpretive meaning often hidden throughout the text and requires the use of inference and understanding the relationship between events and characters or causes and consequences.

\section{3) Critical Reading}

Critical reading is an activity in which the students are able to provide evaluation or take conclusion from a text accurately and compare the ideas in writing. A critical reader must be an active reader, who always asks, looks at the fact contained in the text to understand the meaning of the text itself.

\section{4) Creative Reading}

Creative reading involves going beyond the material presented by the author. It requires readers to think as they read. It can also help students creatively explore their reading skills in which teacher should be able to be a model in teaching learning process.

\subsubsection{Teaching Reading Comprehension}

Brown (2000: 7) states, "Teaching is an activity in which the teacher guides and facilitates learning, gives a chance for the learners to learn, and sets the condition for learning". Guidance is done by leading the students to do activities in the effort of getting knowledge. The teacher can help the students in gaining the knowledge by giving facilities such as tasks. By giving these tasks, the teacher lets the students study by themselves. To make the teaching and learning process run well, the teacher needs to set a good situation for the students to learn. In setting a good condition, the teacher must consider a classroom method or technique that is used as this can influence the way he or she manages the class.

Based on the definition above, teaching reading comprehension is a guidance that is done by the teacher to make learners reach their reading comprehension on the text using a certain technique. Pang, et al. (2003: 14) state "The teacher can lead the learners to understand a text by using some strategies on reading comprehension". The teacher's responsibilities in helping learners achieve these goals is to motivate them by selecting or creating appropriate texts, to design useful reading tasks, to set up effective classroom procedures, to encourage critical reading, and to create supportive environment for practicing reading.

One of the methods that can be applied to teach reading comprehension is Cooperative Learning Method. Wichadee (2004: 9) state that cooperative learning can be an effective way to deal with the problems in EFL classes. It creates a comfortable non-stressful environment for learning and practicing English. It helps students to learn more, have more fun, and develop many other skills such as learning how to work with one another. It can be said that cooperative learning can also be useful in improving the students' reading comprehension. 


\subsubsection{Principles for Teaching Reading Comprehension}

In the teaching of reading, the teacher cannot directly just teach reading to the students by giving texts and asks them to understand it. There are some principles which have to be considered by the teacher. As it is proposed by Harmer (2001: 70-71), there are six principles in teaching reading as described as follows:

a. Reading is receptive. Reading is an incredibly active occupation. To do it successfully, we have to understand what the words mean.

b. Students need to be engaged with what they are reading. As with everything else in lessons, students who are not engaged with the reading text, not actively interested in what they are doing.

c. Students should be encouraged to responds to the content of a reading text, not just to the language. It is important to study reading texts for the way they use language, the number of paragraphs they contain and how many times they use relative clauses.

d. Prediction is a major factor in reading. When read the texts in our own language, frequently have a good idea of the content before we actually read.

e. Match the task to the topic. Once a decision has been taken about what reading text the students are going to read, need to choose good reading task, the right kind of questions, engaging and useful puzzle, etc.

f. Good teachers exploit reading texts to the full. They integrate the reading text into interesting class sequences, using the topic for discussion and further tasks, using the language for study and later activation.

\subsection{Narrative Text}

Narrative text is one of English text types. Narrative text is the text that tells something imaginative or something that is just a fantasy and the goal is only to entertain the reader. Anderson and Anderson (1997: 8) state, "Narrative text is a piece of text which tells a story and in doing so entertains and informs the reader or listener". Meanwhile, Percy (in Permana and Zuhri, 2013:2) states, "Narrative text is a type of essay that tells a story or a series of events in which they occur". Its purpose is to give meaning to an event or a series of events by telling story. Ayres (2008:5) states, "Narrative text is one of the forms of developing writing, for example characters told the history of something based on the development of writing from time to time". From the statements above, it is concluded that a narrative text is a text which contains a story ordered chronologically. In order that the text can be enjoyed by the readers, the writer should arrange the text interestingly. The purpose of telling the story is to give meaning, and to entertain the readers.

\subsection{Cooperative Learning}

Cooperative learning is a kind of teaching strategies that commonly used in the classroom. Brown (2001:47) states "Cooperative learning is one strategy that involves students to work together in pairs or groups and they share information". Furthermore, Richard and Rogers (2001:192) state "cooperative learning is an approach in teaching that maximizes the use of active activity involving pairs or small groups of learner in the class". By implementing cooperative learning, small teams with different levels of ability can use variety of learning activities to improve their understanding of a certain subject.

Slavin (2005:10) states, "Cooperative learning is a teaching method in which students of mixed levels of ability are arranged into groups, and rewarded according to the group's success, not to the success of individual member". Cooperative learning refers to a variety of teaching method in which students work in small groups to help one another learn academic content. In academic classroom, students are expected to help each other, to discus and argue with each other, to access each other's current knowledge and fill in gaps in each other's understanding. In cooperative learning, the students work together in a team or a group to do such kind of task given by their teacher. In these groups, all member of the group can share their ideas in order to finish their tasks. Cooperative learning has been defined as small groups of learners working together as a team to solve a problem, complete a task, or accomplish a common goal.

Cooperative learning consists of some methods, they are: Student Team Achievement Division (STAD), Teams Games Tournament (TGT, Jigsaw, Cooperative Integrated Reading and 
Composition (CIRC), Group Investigation, etc. In this study, Group Investigation method was applied to improve the reading comprehension of the twelfth grade students of SMA Negeri 1 Batang Kuis.

\subsubsection{Group Investigation Method}

Slavin (2005:24) state that Group Investigation method is a method which was developed by Shlomo and Sharan in Tel Aviv University, it is a common class management method where students work in small group use cooperative questions, group by using discuss, and cooperative planning and project. Killen (1998:99) states, "Group investigation method is one of the cooperative learning techniques which focuses on the participation and activities of students". Teachers who use this method should divide the class into small groups. Each group usually consists of two to six students and may form around friendships or around an interest in a particular topic.

Group Investigation method is an organizational medium for encouraging and guiding students' involvement in learning. Students actively share in influencing the nature of events in their classroom. By communicating freely and cooperating in planning and carrying out their chosen topic of investigation, they can achieve more than they would as individuals. The final result of the group's work reflects each member's contribution, but it is intellectually richer than work done individually by the same students. Group Investigation method is a method for classroom instruction in which students work collaboratively in small groups, and take an active part in establishing their learning goals to gain popularity.

\subsubsection{The Procedures of Applying Group Investigation Method}

According to Slavin (2005:218) in the Group Investigation method, the students work through six stages. They are:

a. Identifying the topic and organizing students into group.

1) The students scan source, propose topics, and categorize suggestions.

2) The students join the group studying the topic of their choice.

3) Group composition is based on interest and heterogeneous.

4) The teacher assists in information gathering and facilitates organization.

b. Planning the learning tasks.

The students make the planning together about what do we learn? how do we learn it? who does what? (Divide the assignment) and what are the purposes we investigate the topics?

c. Carrying out the investigation.

The students gather the information, analyze the data, and reach conclusions. Each group member contributes to their group effort. The students share their mind, discuss, clarify, and synthesize all of the idea.

d. Preparing a final report.

1) Group members determine the essential messages of their topic.

2) Group members plan what they will report and how they will make their presentation.

3) Group representatives form a steering committee to coordinate plans for the presentation.

e. Presenting the final report.

1) The presentation is made to the entire class in a variety of forms.

2) Part of the presentation should actively involve the audience.

3) The audience evaluates the clarity and appeal of presentation according to criteria determined in advance by the whole class.

f. Evaluation

1) The students share feedback about the topic, about the work they did, and about their affective experiences.

2) The teacher and student collaborate in evaluating student learning.

3) Assessment of learning should evaluate higher-level thinking.

Slavin (2005: 220) explains the six stages in details as the following.

\section{a. Stage 1: Identifying the topic and organizing into research group}

This stage is devoted to organizational matters. Stage begins with class wide cooperative planning, which can proceed in several ways: 
1) The teacher presents a problem to the entire class and asks," What do you want to know about this problem?" Each student raises questions about the aspect of the problem he or she would like to investigate.

2) Students meet in discussion groups where each person expresses his or her ideas about what to investigate. In each group writes down all ideas and then they reports them to the whole class. A short class discussion result in a shared list of suggestions for subtopics to be investigated.

3) Planning begins with each student writing down his or her suggestions, and continues in progressively larger groups. At each step the group members compare their list and the final list represents the interests of all members.

4) To make all the suggestions available to the whole class, the teacher or students can do this by writing all suggestions on the board. After each student has a list of everyone suggestions, the class classifies them into several categories.

5) Participation in this stage enables students to express their own interests and to exchange ideas and opinions with their classmate. Full, unhurried implementation of this initial planning stage demonstrates that the group learning process is based on individual members"experiences and needs.

6) In the final step of this stage the subtopics are the whole class, usually on the board. Groups are formed based on students' interests; each student joins the group.

\section{b. Stage 2: Planning the investigation in groups}

At this stage group members determine the aspect of the topic. Many groups find it useful to fill out a worksheet containing question relevant to this planning stage. The worksheet may look like this:

\begin{tabular}{l} 
OUR RESEARCH TOPIC : \\
GROUP MEMBERS : (names) \\
WHAT DO WE WANT TO INVESTIGATE? \\
WHAT ARE OUR RESOURCE? \\
HOW WILL WE DIVIDE THE WORK? \\
\hline
\end{tabular}

The teacher can post a copy of each group's worksheet in order to present graphic evidence that the class is a "group of groups". Each student contributes to the small group's investigation, and each group contributes to the whole class study of the larger unit.

\section{c. Stage 3: Carrying out the investigation}

In this stage each group carries out the plans it formulated earlier and need more time. During this stage student, singly or in pairs, gather, analyze, and evaluate information, reach conclusions, and apply their share of new knowledge to the resolution of the group's research problem. Groups may choose to have one member record their conclusions, or each member may present a written summary of his or her findings.

\section{d. Stage 4: Preparing a final report}

This stage is a transition from the data-gathering and classifying stage to the stage where the group reports the results of its activities to the class. At the conclusion of the investigation stage the teacher asks each group to appoint a representative to a steering committee. Of course, students have been telling their group mates all along about what they are doing and learning, but now they begin to plan how to teach their classmates in a more organized fashion the essence of what they have learned.

When teacher meet steering committee, he or she may wish to highlight the following guidelines to help the groups plan their reports:

1) Emphasize the main ideas and conclusions of the investigation.

2) Inform the class about the source the group consulted and how it obtained information. 
3) Allow for questions and answers.

4) Involve classmates as much as possible in the presentation by giving them roles to perform; do not have them sit and listen for long periods.

5) Make sure everyone in the group plays an important role in the presentation.

6) Make sure all necessary equipment or materials have been requested.

e. Stage 5: Presenting the final report

The groups are now prepared to present their final report to the class. These final reports afforded an experience in which intellectual pursuits were accompanied by a moving emotional experience. All members of the class participate in many of the presentations, by performing tasks or answering questions; the presentations were not just a matter of performing rehearsed roles and reciting lines. The following guidelines may helpful:

1) Speak clearly and succinctly when addressing the class, but lecture as little as possible.

2) Use the blackboard to illustrate concepts.

3) Use audiovisual equipment, such as an overhead projector.

4) Conduct formal debates in front of the class if appropriate.

5) Think of preparing learning situations where classmate can perform tasks prepared by the group.

6) Consider dramatizing some portion of the work, or simulating certain events.

7) Consider quiz programs as one way to get an audience interested.

8) Consider displays of pictures, drawing, or photographs to liven up the presentation.

\section{f. Stage 6: Evaluating achievement}

In group investigation teacher should evaluate students ${ }^{\text {ee }}$ higher level thinking about the subject they studied-how they investigated certain aspects of the subject, how they applied their knowledge to the solution of new problems, how they used inferences from what they learned in discussion questions requiring analysis and judgment, and how they reached conclusion from sets of data. This kind of evaluation is best achieved through a cumulative view of the individual's work during the entire investigation project. Teachers and students can collaborate in evaluating student learning. One possible suggestion is peer evaluation.

\section{RESEARCH METHOD}

\subsection{Research Design}

This research is Classroom Action Research (henceforth, CAR). Burns (2010:2) says, "Classroom action research is a part of a broad movement that has been going on in education generally for some time. It is related to the ideas of reflective practice and the teacher as researcher". It means that CAR is a process of research by the teacher for repairing and improving the learning in the classroom. Furthermore, McKay (2006: 29) says, "Action research has three major characteristics: it is carried out by practitioners (i.e., classroom teachers), it is collaborative, and it is aimed at changing things". It means that action research can be done by a teacher in a classroom with the help of other teachers to discuss what and how to improve the classroom activities so that the students' achievement will be better. Based on the definitions above, it is concluded that CAR is form of research in which an idea in a social or educational situation is applied in order to improve or change something to be better, or to get real effect on the situations. In conducting this CAR, the first writer acted as a teacher who applied Group Investigation method in order to improve the students' reading comprehension. The first writer was helped by a collaborator. A collaborator is needed to observe the whole processes of implementing Group Investigation method performed by the first writer in order to improve the students' reading comprehension.

The writers applied CAR model developed by Kemmis and McTaggart (1998). This CAR was arranged into two cycles, namely cycle one and cycle two. Kemmis and McTaggart (1998) state that action research typically involves four broad phases in a cycle of research. The four phases in a cycle are: 1) planning, 2) action, 3) observation, and 4) reflection. The four phases can be seen in the following figure. 


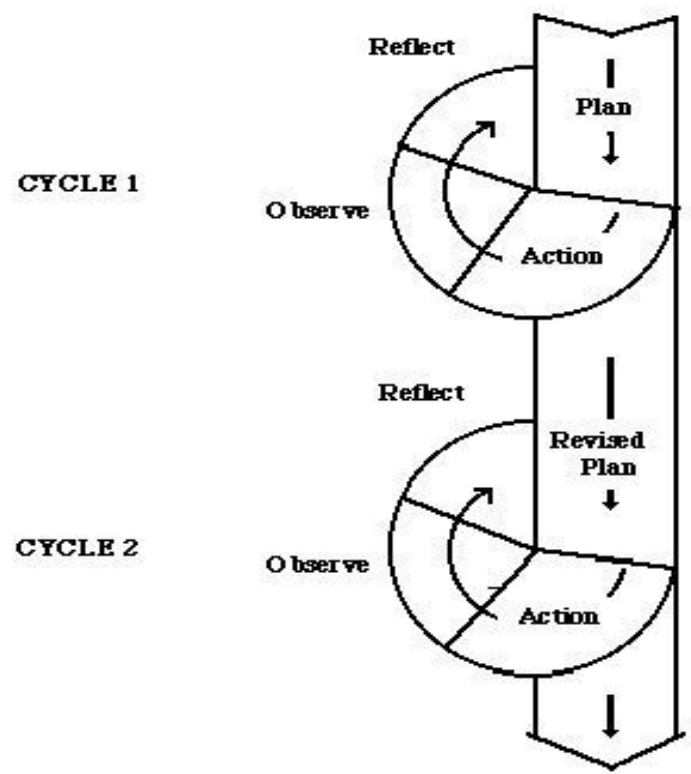

\section{Figure 3.1 The Classroom Action Research (CAR) Model Developed by Kemmis and McTaggart (1998)}

\section{1) Planning}

The four steps in cycle 1 and cycle 2 are explained as follows:

Planning is the first step of CAR procedure. This activity covers the problem identification. This is the most important step in conducting CAR as by knowing the problems, the researchers could find an excellent solution to solve the problems.

\section{2) Action}

In this step, the scenario of learning teaching processes of reading comprehension through the application of Group Investigation method was implemented in the classroom activities.

\section{3) Observation}

Observation was done while the action was taking place. In this step, the students' participation and behaviour and the teacher's action during the learning teaching processes of reading comprehension through the application of Group Investigation method were observed by the collaborator. It was done in order to get the actual data. The obtained data were used as a reflection in order to improve the quality of learning teaching processes of reading comprehension through the application of Group Investigation method.

\section{4) Reflection}

The data which were obtained such as the students' reading comprehension scores in the pretest, formative test, and posttest, the extent of students' participation and behaviour, and the teacher's action during the learning teaching processes of reading comprehension through the application of Group Investigation method were collected and analyzed. In brief, the quantitative and qualitative data were analyzed to assess the students' progress or achievement in learning reading comprehension through the application of Group Investigation method.

\subsection{The Subject of the Research}

The subject of the research is the twelfth grade students of SMA Negeri 1 Batang Kuis Class XII IPA 5 in the Academic Year of 2017/2018. The numbers of the students in that class are 32 students, consisting of 24 female students and 8 male students.

There are two reasons why the writers chose the school as the location of the research. First, based on the preliminary research that was done by the writers, it is needed to improve the reading comprehension of the twelfth grade students of SMA Negeri 1 Batang Kuis Class XII IPA 5 in the Academic Year of 2017/2018 through Group Investigation method. Second, based on the writers' knowledge there has never been any research about improving students' reading comprehension through Group Investigation method. 


\section{DATA ANALYSIS}

Based on the data analysis, it was found that Group Investigation method can improve the students' reading comprehension. It was proven by the students' mean score which kept increasing from the pretest to posttest. The students' mean score in the pretest is $60.25,71.25$ in the formative test, and 78.87 in the posttest. In the formative test, the percentage of the students' who got score $\geq 75$ is higher than that in the pretest and also in the posttest, the percentage of the students' who got score $\geq 75$ is higher than that in the formative test. It means that the application of Group Investigation method truly helps the students improve their reading comprehension.

The students' responses towards the learning processes of reading comprehension through the application of Group Investigation method are very positive. The application of Group Investigation method helps them become active readers. They are motivated to learn and comprehend narrative texts. Based on the result of the questionnaire, all the students agree that Group Investigation method is appropriate to improve their reading comprehension, especially on narrative texts. Thus, it is concluded that Group Investigation method can improve the students' reading comprehension successfully.

\section{CONCLUSIONS AND SUGGESTIONS \\ 5.1 Conclusions}

After analyzing and discussing the data, the writers draw the following conclusions:

1) Group Investigation method can improve the students' reading comprehension. It could be seen from the increasing of the students' mean score from the pretest to the posttest. The students' mean score in the pretest is $60.25,71.25$ in the formative test, and 78.87 in the posttest. Meanwhile, the students' score percentage who passed Mastery Minimum Criteria (Kriteria Ketuntasan Minimal (KKM)) from pretest is $15.62 \%$, the formative test is $25 \%$, and posttest is $71.87 \%$. To sum up, the students' mean score and the percentage of the students who passed the Mastery Minimum Criteria (Kriteria Ketuntasan Minimal (KKM)) continuously increased in each test. Therefore, it is concluded that Group Investigation method can improve the students' reading comprehension on narrative texts successfully.

2) Based on the results of field notes, observation sheets, and questionnaire, it was found that the students responded positively to the application of Group Investigation method. They were motivated to learn and comprehend narrative texts while Group Investigation method was being applied in the learning teaching processes of reading comprehension.

\subsection{Suggestions}

The writers would like to give some suggestions as follows:

1. For the English teachers

The English teachers should be more creative and innovative to select a teaching method to deliver their learning materials. They could find a good method to get their students' interest in learning English, especially in learning reading comprehension. The writers suggest that the English teachers apply Group Investigation method to improve their students' reading comprehension.

2. For the students

The students had better read English texts as many as possible to improve their reading comprehension. They should be active in the classroom activities. They can use Group Investigation method as one of alternatives to help them improve their reading comprehension.

3. For other writers

The results of this study are expected to be able to provide other writers valuable information about how to improve students' reading comprehension through the application of Group Investigation method. 


\section{BIBLIOGRAPHY}

Anderson, M., \& Anderson, K. 1997. Text Types in English. Sidney: Macmillan Education Australia PTY LTD.

Arikunto, S. 2002. Prosedur Penelitian Suatu Pendekatan Praktik (Edisi Revisi V). Jakarta: Rineka Cipta.

. 2006. Penelitian Tindakan Kelas (Classroom Action Research). Jakarta: Bumi Aksara.

Ayres, L. 2008. Narrative Texts. New York: Plenum Press.

Best, J. K., \& Kahn, J. V. 2002. Research in Education (9 ${ }^{\text {th }}$ Edition). Reno: Allyn Bacon.

Brassel, D., \& Rasinski, T. 2008. Comprehension that Works. Huntington Beach: Shell Education.

Brown, H. D. 2000. Principles of Language Learning and Teaching. New York: Longman. 2001. Teaching by Principle: An Interactive Approach to Language Pedagogy. New York: Longman.

2004. Language Assessment: Principles and Classroom Practices. New York: Pearson Education.

Burns, A. 2010. Doing Action Research in English Language Teaching: A Guide for Practitioners. New York: Routledge.

Burn, P. C., Roe, B. D., \& Ross, E. P. 1990. Teaching Reading in Today's Elementary School. Boston: Houghton Mifflin Company.

Cain, K. 2010. Reading Development and Difficulties. West Sussex: British Psychological Society and Blackwell Publishing.

Febriyono, H. 2015. The Use of Group Investigation Method to Improve Students' Reading Skill at the Tenth Grade Students of SMK Negeri Jumantono. An Unpublished Sarjana's Thesis, Faculty of Teachers Training and Education: Slamet Riyadi University.

Grabe, W., \& Stoller, F, L. 2002. Teaching and Researching Finding. Edinburg: Pearson Education.

Harmer, J. 2001. How to Teach English. Cambridge: Longman.

Kemmis, S., \& McTaggart, R. 1988. The Action Research Planner (3 ${ }^{\text {rd }}$ Edition). Geelong: Deakin University Press.

Killen, R. 1998. Effective Teaching Strategies: Lessons from Research and Practice. Sydney: Social Science Press. 
Klingner. 2007. Teaching Reading Comprehension to Students with Learning Difficulties. New York: The Gulidford Press.

Lucantoni, P. 2005. Teaching and Assessing Skills in English as A Second Language. Cambridge: Cambridge University Press.

Martin, D. 1991. How to be A Successful Students. California: Marin Trails Publishing LLC.

McKay, S. L. 2006. Researching Second Language Classrooms. London: Lawrence Erlbaum Associates.

Nunan, D. 2003. Practical English Language Teaching. New York: Mc Graw Hill.

Pang, S, et al. 2003. Teaching Reading. Brussels: International Academy of Education (IAE).

Permana, T. D., \& Zuhri, F. 2013. The Implementation of Picture Series as Media in Teaching Writing of A Narrative Text of the Tenth Graders of Senior High School. Journal of Retain, 1 (1), 1-8.

Rahmawati. A. 2014. The Use of Group Investigation Strategy to Improve Students' Reading Skill at the Tenth Grade of MAN Tengaran. An Unpublished Sarjana's Thesis, Faculty of Teachers Training and Education: State Institute For Islamic Studies Salatiga.

Richards, C. J and Rodgers, S. T. 2001. Approaches and Method in Language Teaching. Cambridge: Cambridge University Press.

Sharan, Y \& Sharan, S. 1992. Group Investigation: Expanding Cooperative Learning. NewYork: Teacher's Collage Press.

Slavin, R. E. 2005. Cooperative Learning Theory, Research and Practice. London: Allymand bacon.

Snow, C. 2002. Reading for Understanding: Toward An R\&D Program in Reading Comprehension. Washington DC: Rand Corporation.

Sulistiono, L. 2011. Improving Students' Reading Skill through Group Investigation Method at the Eleventh Grade of MA Arrisalah Ponorogo. Unpublished Sarjana's Thesis, Faculty of Teachers Training and Education: State Islamic College Tulungagung.

Tan, I. G. et al. 2006. Group Investigation and Students Learning: An Experiment in Singapore Schools. Singapore: Marshal Cavendish Academic.

Wichadee, S. 2004. The Effects of Cooperative Learning on English Reading Skills and Attitudes of the First-Year Students at Bangkok University. Bangkok: Bangkok University Press.

Woods, C. 2005. Teaching and Assessing Skills in English As AForeign Language. Cambridge: Cambridge University Press. 